\title{
Extraordinary action in matters of general health and its impact on health care personnel
}

\author{
La acción extraordinaria en materia de salubridad general y su repercusión en el personal de \\ salud
}

Alejandro Pacheco-Gómez ${ }^{a}$

\begin{abstract}
:
The extraordinary action in matters of general health is a measure to prevent, combat and avoid health risks such as serious epidemics, the presence of exotic diseases or the danger of invasion of communicable diseases, by means of which the exercise of some rights is restricted to safeguard public health, supported by provisions of the Mexican Constitution for a legitimate and nonarbitrary application.
\end{abstract}

Keywords:

Sanitary Action, Human Rights, Public Health

\section{Resumen:}

La acción extraordinaria en materia de salubridad general es una medida para prevenir, combatir y evitar riesgos a la salud como epidemias graves, presencia de enfermedades exóticas o peligro de invasión de enfermedades transmisibles, por medio de la cual se restringe el ejercicio de algunos derechos para salvaguardar la salud pública, sustentada en disposiciones de la Constitución Política de los Estados Unidos Mexicanos para una aplicación legítima y no arbitraria.

\section{Palabras Clave:}

Acción Sanitaria, Derechos Humanos, Salud Pública

\section{INTRODUCTION}

A crucial note in the Rule of Law is the existence of a law framework that regulates the activity of those who hold public power - especially authorites- so their actions are not arbitrary. There are exceptional situations in which it is necessary to adopt special measures to face and preserve legal assets of great value. Today, we are in a sanitary emergency caused by SARS-CoV2 virus responsable for COVID-19 disease. This is why, one more time, the extraordinary action was executed regarding general health. It is a measure that constitutionally corresponds to the federal health authorities, therefore, the local authorities cannot apply it. Through this action, it is legally possible to limit the exercise of some human rights and impose obligations to the health care personnel, within the limits that the same law establishes. In this research work, it will be reviewed what this extraordinary action is about, which are the motives to apply it, which authorities are involved, what it its scope, and the which have been the situations where it has been applied always respecting the Mexican Constitution and applicable laws and regulations. All of the former because, although there have been several months since the sanitary emergency was declared by the General Health Council and the Federal Health Secretary has pronounced the health care measures, the context of such actions is still not clear [1]. Primma facie, it would seem more like a legal topic more than a sanitary one, but it is a topic of interest not only for legal professionals, but also for the sanitary health care personnel because the consequences of their professional work transcend.

\section{CONCEPT}

To build a concept of the extraordinary action regarding general health is not simple. In fact, there are not many doctrinal contributions about it ${ }^{*}$. Therefore, their elements will be mentioned through its legal regulation on the basis of both, the Mexican Constitution and the General Health Law.

\footnotetext{
* That is why bibliography is scarce.
}

\footnotetext{
a Correspondence Author, Universidad Autónoma del Estado de Hidalgo, Instituto de Ciencias para la Salud. Email: alejandro_pacheco@uaeh.edu.mx
} 
According to articles 73, section XVI, 2nd Base, of the Constitution and article 181 of the General Health Law, before a sanitary emergency, the head of the Ministry of Health (of the Federal Government) will dictate the immediate measures that are crucial to prevent and avoid health damages, subject to the subsequent confirmation of the President of Mexico.

Therefore, the legal asset to be protected is mainly public health, since such provisions mention serious epidemics and the presence of communicable or exotic diseases.

This way, the measures established by those sanitary authorities constitute the application of the extraordinary action regarding general health. It is an action because the conduct of the authorities is translated in "doing" in order to protect the public health. People talk about general health in the sense of a topic of national interest so the obligation is for the federal authorites to make it valid in all the Mexican territory. And it is extraordinary precisely because of the special scenario that emerges as an exceptional situation.

The article 4 of the Constitution, recognizes the right to health protection, which is defined by article $1^{\circ}$ Bis as a state of complete physical, mental and social wellfare, and not only the absence of illnesses or diseases.

In this sense, doctrine has identified the medical attention and social assistance as actions of health protection (Pacheco y Pacheco, 2020). The sanitary action refers to the intervention of the State to protect people's health. There are two types of actions: ordinary and extraordinary. The first one refers to the activities of public health and sanitary surveillance, since it is performed on a daily basis. The second one is precisely applied in exceptional situations like the ones already mentioned.

The reason why is because, to protect the health, not only medical attention is given, but also the measures to face health risks for the collectivity are crucial. The Romans already said salud populi, suprema lex est -people's health should be the supreme law -.

\section{CAUSES}

In terms of the legal provisions mentioned, the causes that are identified to apply this action are the following:

a) Serious epidemics;

b) Danger of invasión of exotic diseases;

c) Danger of invasion of comunicable diseases;

d) Situations of emergency or catastrophe that affect the country, and

e) Emergency caused by the suddend deterioration of the environment.

As it was mentioned, according to the exposed causes, the intervention of the authorities will be with the purpose of maintaining public health and, consequently, individual health.

\section{AUTHORITIES THAT INTERVENE}

The General Health Law, in its article 4, lists the sanitary authorities:
a) President of Mexico;
b) Ministry of Health;
c) General Health Council, and
d) Local governments.

The participation of each one of these authorities has a sequencial order according to the legal provisions that rule the application of this action.

1) General Health Council:

It is a collegiate body that depends directly from the President of Mexico and it is presided by the head of the Ministry of Health and has legal, consulting and executive functions*.

The article 15 of the General Health Law provides that it will integrated by, besides its Chairman, by a Secretary and thirteen regular members who are:

I. The Secretary of Finance and Public Credit;

II. The Secretary of Social Development (now the Secretary of Wellfare);

III. The Secretary of Environment and Natural Resources;

IV. The Secretary of Economy;

V. The Secretary of Agriculture, Livestock, Rural Development, Fishing and Food;

VI. The Secretary of Communications and Transportations;

VII. The Secretary of Public Education;

VIII. The Head of the Mexican Social Security Institute (IMSS);

IX. The Head of the Social Service and Security Institute for Government Employees (ISSSTE);

X. The General Director of the National System for Family Development (DIF);

XI. The Chairman of the National Academy of Medicine in Mexico (Academia Nacional de Medicina de México, A. C.); XII. The Chairman of the Mexican Academy of Surgery (Academia Mexicana de Cirugía, A. C.), and

XIII. The President of the National Autonomous University of Mexico (UNAM).

The Council's attributions related to the topic of this research are mainly:

- To dictate the measures that aim at preventing and combating the harmful effects of enviaronmental pollution in people's health;

- To approve the necessary agreements and other general provisions of mandatory observance in the country regarding general health, within their competence area, and

- To approve and publish in the Official Federal Journal the statement about the cases of serious diseases that are a cause of emergency or jeopardize the national health, by own initiative or by written

\footnotetext{
* Artículo 1 del Reglamento Interior del Consejo de Salubridad General.
} 
request of national institutions specialized in the disease, that are accredited by the Council, in which it is duly supported the need for primary attention.

Therefore, it corresponds to the Council to declare the existance of a sanitary emergency that requires primary attention. This way, as one of the highest authorities of the country, it has the responsibility of determining with that declaration, that it will be necessary that the head of the Ministry of Health apply the extraordinary action regarding general health.

Today, the Council has issued the following agreements:

- Agreement by means of which the General Health Council recognizes the epidemic by the SARS-CoV2 (COVID-19) in Mexico, as a serious disease of primary attention, and also the preparation activities and response are established to face the epidemics, published in the Official Federal Journal on March 23, 2020.

- Agreement by means of which the sanitary emergency is declared by force majeure, to the epidemic generated by SARS-CoV2 virus (COVID19), published in the Official Federal Journal on March 30, 2020.

These two Agreements preceded those issued by the Secretary of Health by doing the extraordinary action. This means that, in order for the Secretary of Health to issue the provisions, it is required that the General Health Council do the corresponding declaration that encourages this action.

2) Secretary of Health:

The Secretary of Health, like the rest of the Secretaries of State, is freely designated and removed by the President of Mexico. He/she is in charge of nacional health politics. From the already mentioned regulations, it is clear that this officer is in charge of dictating the measures that will constitute this extraordinary action. It is the only Secretary of State who has express constitutional faculties, even prior to the intervention of the President of Mexico.

This action is carried out by issuing an administrative Agreement, since it is the one allowed by administrative and constitutional provions. Therefore, in this sanitary emergency the following documents have been issued:

- Agreement that establishes the preventive measures that must be implemented to mitigate and control the health risks of SARS-CoV2 (COVID-19), published in the Official Federal Journal on March 24, 2020.

- Agreement that establishes the extraordinary measures to deal with the sanitary emergency generated by the SARS-CoV2 virus, published in the Official Federal Journal on March 31, 2020.
Derived from these Agreements, the Secretary of Health issued several documents that could be considered a complement to update the measures that will evolve as the epidemilogical situation evolves.

Primarily, the non-essential activities were suspended and rules were set up for those that were considered essential activities. This led to the suspension of for example, the right of reunion.

However, the documents related to the return to non-essential activities have already been issued with the purpose of establishing the measures of prevention and protection in social interaction.

3) President of Mexico:

The President of Mexico is the Head of State and Head of the Government. In the first case, he/she is in charge of representing the Mexican State abroad; as Head of the Government, he/she is in charge of the Federal Public Administration, this means, the structure that legal regulations establish to make the rights embodied in the laws come true through the provision of a service and the granting of goods.

Article 4, section I, of the General Health Law, gives him/her the character of health authority.

His/her intervention in this extraordinary action of general health, is to validate th immediate provisions dictated by the Secretary of Health. This refers to the validation as a solemn confirmation on behalf of the Head of the Government, this is, expressing his/her agreement with the established measures. Currently, this validation was materialized with the Decree that validates the Agreement that establishes the preventive measures that must be implemented to mitigate and control the health risks of SARS-CoV2 (COVID-19), published in the Official Federal Journal on March 24, 2020.

A cronological order is noticed in the issuance of the different administrative documents: first the General Health Council, then the Secretary of Health and finally, the President of Mexico.

4) Local Governments:

Even when they are considered health authorities, the exercise of this extraordinary action is a faculty specifically grante to federal authorities, so the States will only comply with the dictated provisions.

Nevertheless, in the case of comunicable diseases, particularly articles 134 and 139 of the General Health Law, allow the local governments to do activities of epidemiological surveillance, prevention and control of communicable diseases, like:

- Isolation, for as long as it is strictly necessary, of sick people, of those suspected of having the disease, and germ carriers, as well as the limitation of their activities when it is necessary for epidemiological reasons. 
- The observation, as needed, of human and animal contacts.

- The application intravenous, vaccinations and other preventive and therapeutical resources.

- The microbial and parasite decontamination, disinfection and disinsection of zones, romos, clothes, utensils and other objects exposed to contamination.

- The inspection of passenger who could be germ bearers, as well as luggage, godos, and other objects that could sources of vehicles of pathogenic agents.

In consequence, several Governors of the States issued Agreements like the following, in the State of Hidalgo:

- Agreement that establishes the immediate sanitary measures for prevention and control of the infectious disease caused by COVID-19 in the State of Hidalgo, published in the Official Local Journal on March 19, 2020.

- Agreement that establishes the measures and actions that must be implemented by public offices and organisms part of the local administration due to COVID-19 in the State of Hidalgo, published in the Official Local Journal on March 25, 2020.

- Agreement of the Secretary of Health that establishes the guidelines to manage death bodies in suspicious and confirmed cases of COVID-19 in the State of Hidalgo, published in the Official Local Journal on Marhc 27, 2020.

- Agreement by means of which the immediate sanitary measures are extended to prevent and control the infectious disease caused by COVID-19 in the State of Hidalgo, published in the Official Local Journal on April 3, 2020.

- Agreement that establishes the use of masks as a preventive complementary measure with high impact against the propagation of COVID-19 in the State of Hidalgo, published in the Official Local Journal on April 28, 2020.

Because each state is autonomous regarding their internal regime, there are many agreements in each one of them.

\section{DICTATED MEASURES}

The sanitary authorities are executive authorites, so their decisions are enforceable for all the authorities in the country. These measures can have the power to restrict some human rights. In this regard, the article 184 of the General Health Law establishes the following:

- To entrust to federal, local and municipal authorities, as well as to professional, technicians and assistants of health disciplines, the necessary actions to encourage the participation of individuals.
- To dictate the sanitary measures related to people reunions, their entry and exit rules, and the special hygiene regime that must be implemented, depending on the specific case.

- To control the terrestrial and aerial traffic, as well as to freely use all the means of transportation property of the state and public service, whatever the legal regime the former are subject to.

- To freely and primarily use the telephone, telegraphic and mail services, as well as radio and TV broadcasting services.

These measures are not only addressed to the general public, but are also mandatory for healthcare personnel. This means that in exceptional situations, they are entrusted with labors specific of their position context as guarantor of the human right to health protection; from a bioethical perspective, they assume the exercise of the beneficence principle.

Regarding human rights, these duties sometimes imply the restriction of their free professional practice, but they are justified to accomplish the protection of public health.

Some of these measures are:

- To inform to the authorities the cases of communicable diseases.

- When knowing about a case of communicable disease, they are obliged to take the necessary measures, accoring to the nature and characteristics of the condition, applying the available resources to protect the individual and collective health.

- To provide to the sanitary authorities with all the medical and social assistance resources of the public, social and private sectors in the affected zone and its sorroundings.

- To carry out the actions that the sanitary authorities consider necessary.

This way, the health care personnel will help the sanitary authorities by providing professional services according to the established sanitary measures with the purpose of preventing, controlling, and avoiding the propagation of these communicable diseases.

Taking into consideration the sanitary risks, the rights that are most affected are the reunion, mobility, and work liberties, as it is about avoiding or reducing the gathering of people. Regarding health care personnel, they are obliged to provide their services in a special way, even their normal schedule and place of work is changed.

It is the authority's duty to balance the motives, effects and purposes of the restrictive measures, aiming at avoiding arbitraty decisions. Therefore, within the limits of the Rule of Law, there are principles of reasonability and proportionality; the first one demands that the measure is justified, while the second one prevents it from being excessive. 


\section{OCCASIONS WHEN THE EXTRAORDINARY MEASURE HAS BEEN APPLIED IN THE GENEARL HEALTH FIELD}

The first occasion was in April 2009 through a presidential decree to face the influenza epidemic. At that moment, the President of Mexico directly exercised the power given to the Secretary of Health, by commanding the implementation of sanitary measures for that effect. There was not a strict compliance to the article 73 of the Mexican Constitution, since it was not the Secretary of Health who firstly dictated the measures. In the second case, the Secretary of health issued the agreement about the preventive measures to combat the ebola virus disease. Later, the President of Mexico approved the corresponding Secretary Agreement through a Decree published in the Official Federal Journal the same October 24, 2014. In both cases, the restriction of human rights was expected, like the right to mobility, reunion, even the entrance to houses to control and combat the epidemic. Also, the members of the National Health System were obliged to comply with the provisions dictated by the sanitary authorities.

\section{CONCLUSIONS}

The extraordinary action regarding general health is a measured established by the authority to face sanitary emergencies with the purpose of protecting public health, implying human rights restrictions such as right to mobility, reunión, ore ven the profesional practice of health care personnel by making them provide their service under specific conditions, preserving at all moment people's dignity. Nevertheless, this action must be applied within the constituonal and legal framework so it does not become an arbitraty action, making it a justified and non-excessive action to guarantee the right to health protection.

\section{REFERENCES}

Pacheco, U. \& Pacheco A. (2020).Origen y sentido de la medida de extraordinaria en salud: el Consejo de Salubridad General [Internet]. [Citado 17 de septiembre de 2020]. Disponible: https://eljuegodelacorte.nexos.com.mx/?author_name=alejandropacheco-gomez.

CasaMadrid Mata,O. (2005).La atención médica y el derecho sanitario: Editorial Alfil; XII. 